\title{
SURVEY GROSS MOTOR ACTIVITY SISWA FULL DAY SCHOOL DAN REGULER SEKOLAH DASAR SE-KECAMATAN KOTA SUMENEP MELALUI BASIC MOTOR ABILITY TEST- REVISED
}

\author{
Shally Nordiansyah ${ }^{1}$, Dyas Andry Prasetyo² \\ 1,2 STKIP PGRI Sumenep \\ E-mail: shallynordiansyah@stkippgrisumenep.ac.id ${ }^{1}$, dyasandry@stkippgrisumenep.ac.id² \\ DOI: https://doi.org/10.36526/kejaora.v5i2.1005
}

\begin{abstract}
ABSTRAK
Di kabupaten Sumenep ada beberapa sekolah dasar yang melaksanakan kegiatan Full Day School dan Reguler. Tentunya ini akan berakibat terhadap tingkat kebugaran jasmani dan motorik kasar siswa sekolah dasar tersebut. Bukan rahasia lagi bahwa kebugaran jasmani dan motorik dapat mempengaruhi aktivitas belajar mengajar di dalam kelas. Basic Motor Ability - Revised adalah sebuah pengujian berdasarkan norma yang digunakan untuk menilai respon kontrol otot besar dan otot kecil yang dipilih. Penelitian ini adalah penelitian deskriptif yang dilakukan untuk menggambarkan gejala,fenomena atau peristiwa tertentu (Maksum 2012:68). Metode yang digunakan dalam penelitian ini adalah kuantitatif. Penelitian ini dinamakan dekriptif kuantitatif yang tujuanya menggambarkan suatu fenomena berdasarkan angka-angka yang diperoleh. Hasil yang diproleh untuk Full Day School, Tes Koordinasi Mata Tangan dengan skor 4,tes keseimbangan statis dengan skor 18.5 kategori sedang, tes menendang bola dengan skor 2 dengan kategori sangat kurang dan tes kelincahan dengan skor 15.46 dengan kategori sangat kurang. Untuk Regular School Tes Kordinasi Mata Tangan dengan skor 7,tes keseimbangan statis dengan skor 23 kategori sedang, tes menendang bola dengan skor 4 dengan kategori kurang dan tes kelincahan dengan skor 13.41 dengan kategori baik.
\end{abstract}

Kata Kunci: Survey, Full Day School, Regular School, BMAT-R

\section{PENDAHULUAN}

Pendidikan merupakan salah satu cara untuk seseorang merubah nasibnya kea rah yang lebih baik sebab dengan pendidikan akan merubah mindset seseorang untuk berpikir lebih dari biasanya. Pendidikan merupakan pengajaran untuk mentransfer Imu dari seseorang yang dianggap mampu untuk memtransfer ilmu dan keahlian. Pendidikan umumnya didapatkan di sekolah sebagai wadah untuk belajar. Di sekolah biasanya terdapat dua pendidikan yaitu pendidikan akademik dan pendidikan non akademik. Akademik berhubungan dengan transfer ilmu sedangkan pendidikan non akademik mentransfer bidang keahlian.

Pendidikan jasmani atau penjas merupakan cabang ilmu yang dalam penerapannya banyak melibatkan aktivitas fisik. Aktivitas fisik yang diterapkan di dalam pembelajaran penjas bertujuan untuk meningkatkan aspek kognitif, afektif dan psikomotor siswa. Penjas bertujuan menggali potensi siswa sesuai dengan muatan yang tercantum dalam kurikulum 2013. Menurut kurikulum 2013 penjas di sekolah harus memberikan dampak terhadap perubahan kognitif, afektif, dan psikomotor siswa. Ketiga aspek tersebut diharapkan oleh kurikulum 2013 (PPPPTK Penjas dan BK Kementrian Pendidikan dan Kebudayaan, 2013 : 141)

Olahraga merupakan salah satu alat untuk mengukur tingkat kebugaran dari manusia itu tersebut. Banyak hal yang dilakukan manusia untuk mengetahui tingkat kebugaranya, salah satunya adalah bermain melalui permainan olahraga.

UU No 3 Tahun 2005, Sistem Keolahragaan Nasional Pasal 25 ayat (1) yang menyatakan bahwa pembinaan dan pengembangan olahraga pendidikan dilaksanakan dan diarahakan sebagai satu kesatuan yang sistematis dan berkesinambungan dengan sistem 
Jurnal Kejaora: Jurnal Kesehatan Jasmani dan Olah Raga

ISSN: 2541-5042 (Online)

ISSN: 2503-2976 (Print)

Volume 5 Nomor 2, Edisi November 2020

pendidikan nasional. Menurut Hasbullah (2003:46) yang dimaksud dengan pendidikan sekolah disini adalah pendidikan yang diperoleh seseorang secara teratur, sistematis, bertingkat dan dengan mengikuti syarat-syarat yang jelas dan ketat ( mulai dari Taman Kanak-kanak sampai perguruan tinggi). Hal itu tentu tidak terlepas dari tujuan pendidikan nasional lebih lanjut dinyatakan dalam Peraturan Pemerintah nomor 16 tahun 2007 tentang penyelengaraan keolahragaan pasal 25 (1) menyatakan bahwa pembinaan dan pengembnagan olahraga pendidikan bertujuan untuk memeroleh pengetahuan, kepribadian, keterampila, kesehatan dan kebugaran jasmani serta pengembangan minat dan bakat olahraga (Pemerintah Republik Indonesia, 2007). Pendidikan jasmani di sekolah dasar pada hakekatnya mempunyai arti, peran fungsi yang amat vital dalam upaya menciptakan suatu masyarakat yang sehat dan dinamis (Kiram, 1992).

Kita semua mengetahui pada dasarnya sekolah merupakan sebuah wadah untuk mengembangkan seseorang. Dalam hal perkembangan ini tetntunya tidak dapat dipisahkan dari sebuah kemampuan akademik dan kemampuan non akademik. Menurut Nasution dalam (Prasetyo Baskoro Adi, 2010:372), menyatakan kemampuan akademik merupakan salah satu faktor yang berpengaruh terhadap prestasi belajar siswa. Sedangkan kemampuan non akademik ialah kemampuan yang tidak memiliki hubungan dengan pengetahuan yang memiliki sifat ilmiah.

Kabupaten Sumenep merupakan kabupaten yang berada di provinsi Jawa Timur tepatnya Kabupaten paling ujung timur di pulau Madura. Berbicara pendidikan di kabupaten Sumenep tentulah merupakan hal sangat menarik untuk dipelajari lebih mendalam agar Kabupaten Sumenep juga tidak ketinggalan dalam hal pendidikan dengan Kabupaten/Kotamadya yang sudah lebih maju pendidikannya.

Di Kabupaten Sumenep terdapat sekolah yang menerapkan Full Day School

Tabel 1. Item Tes BMAT-R

\begin{tabular}{ccc}
\hline \multicolumn{1}{c}{ No } & Item Tes & Tujuan \\
\hline 1 & Menguntai manik - manik & Koordinasi mata tangan dan ketangkasan \\
\hline
\end{tabular}




\begin{tabular}{lll}
\hline 2 & Sasaran Lempar & Koordinasi mata tangan hubunganya dengan melempar \\
\hline 3 & Memainkan kelereng & Ketangkasan jari dan kecepatan gerak tangan \\
\hline 4 & Meregang otot lutut dan punggung & Kelentukan \\
\hline 5 & Lompat jauh tanpa awalan & Kekuatan dan power otot kaki bagian bawah dan paha \\
\hline 6 & Berdiri sambil nunduk & Kecepatan dan kelincahan \\
\hline 7 & Keseimbangan statis & Keseimbangan dengan mata terbuka dan tertutup \\
\hline 8 & Melempar bola basket & Eksplosif otot tangan kekuatan otot bahu \\
\hline 9 & Memukul bola & Kordinasi gerak memukul \\
\hline 10 & Menendang ke sasaran & Kordinasi mata dan kaki \\
\hline 11 & Kelincahan & Kemampuan mengubah arah dengan cepat \\
\hline
\end{tabular}

Soapatty (2014) berdasarkan unsurunsur dalam penerapan sistem Full Day School maka dapat dimaksudkan atau diartikan bahwa unsur yang menunjang dalam penerapan sistem Full Day School adalah adanya pengaturan jadwal yang baik, pembelajarannya harus memiliki strategi yang sangat baik dalam melaksanakan suatu pembelajaran, fasilitas yang menunjang serta menggali lebih dalam lagi tentang materi yang akan atau sudah diberikan Peneliti mempunyai asumsi bahwasanya sekolah yang menerapkan system Full Day School itu mempunyai pengalaman gerak yang kurang baik. Hal itu bisa dilihat dari waktu mulai sekolah dan berkahirnya jam sekolah, sehingga ketika anak sudah pulang ke sekolah pada siswa Full Day School siswa akan merasa capek karena banyak waktu yang tersita di sekolah untuk belajar materi, berbeda dengan sekolah yang menerapkan regular School, mereka para siswa lebih banyak mendapatkan pengalaman gerak yang diperoleh ini bisa terlihat dari jam pulang sekolah tersebut yang hanya maksimal jam 12.00 wib. sehingga memungkinkan siswa untuk beristirahat menghilangkan penat dari kegiatan sekolah yang dilakukan sebelumnya dan di sore hari siswa bisa mengikuti kegiatan baik pengembangan diri yang dilakukan oleh sekolah tersebut atau bahkan siswa tersebut mengikuti klub pelatihan sesuai bakat dan minat yang mereka senangi utamanya perkumpulan pelatihan yang erat kaitanya dengan gerak. Dari hal tersebut diatas jelaslah sangat berbeda antara jam pulang siswa Full Day School dan regular School. Hal ini tentunya akan sangat berpengaruh terhadap gerak dari siswa tersebut menurut asumsi peneliti. Dari hal tersebut sangatlah perlu untuk diketahui tingkat kualitas gerak dari dua sekolah tersebut sehingga perlu dilakukan survey gerak siswa full day School dan regular School yang nantinya bisa dijadikan dasar untuk menilai sejauh mana gerak yang baik dan efektif di kedua sekolah tersebut. Dari masalah tersebut inngin melakukan penelitian terkait hal tersebut dengan mengangkat masalah "Survey Gross Motor Activity Siswa Full Day School Dan Reguler Sekolah Dasar Se - Kecamatan Kota Sumenep Melalui Basic Motor Ability Test - Revised"

\section{METODE}

Penelitian ini adalah penelitian
deskriptif yan dilakukan untuk menggambarkan gejala, fenomena atau peristiwa tertentu (Maksum, 2012). Metode yang digunakan dalam penelitian ini adalah kuantitatif. Sehingga penelitian ini dinamakan dekriptif kuantitatif yang tujuanya menggambarkan suatu fenomena berdasarkan angka-angka yang diperoleh. Dalam Penelitian ini menggunakan Sampling Purposive yang digunakan karena pertimbangan tertentu, (Winarno, 2011). Instrumen Menggunakan Buku Panduan Penetapan Parameter Tes Pada Pusat Pendidikan dan Pelatihan Pelajar dan Sekolah Khusus Olahragawan tahun 2005.

\section{HASIL DAN PEMBAHASAN \\ Kordinasi Mata dan Tangan}

Pada bulan Mei peneliti mengadakan penelitian sekolah yang dimaksud dengan tujuan mendapatkan informasi terkait penelitian yang dilakukan peneliti. Untuk data Tes Koordinasi mata tangan diperoleh data sebagai berikut: 
Jurnal Kejaora: Jurnal Kesehatan Jasmani dan Olah Raga

ISSN: 2541-5042 (Online)

ISSN: 2503-2976 (Print)

Volume 5 Nomor 2, Edisi November 2020

Tabel 2. Hasil tes Kordinasi Mata dan Tangan

\begin{tabular}{cccc}
\hline \multicolumn{2}{c}{ Regular Schooll } & \multicolumn{2}{c}{ Full Day Schooll } \\
\hline $\begin{array}{c}\text { SDN } \\
\text { Pangarangan V }\end{array}$ & $\begin{array}{c}\text { SDN } \\
\text { Pangarangan I }\end{array}$ & SDIT Al-Hidayah & $\begin{array}{c}\text { SD Integral } \\
\text { Luqman Al-Hakim }\end{array}$ \\
\hline 176 & 232 & 111 & 118 \\
\hline 5.86 & 7.73 & 3.7 & 3.93 \\
\hline
\end{tabular}

Dari data hasil tes tersebut dapat diketahui bahwasanya pada hasil Kordinasi Mata Tangan Regular School pada SDN Pangarangan V mendapat skor 176 dan dengan rata-rata 5.8 atau dibulatkan menjadi 6. Pada SDN Pangarangan I mendapat 232 dan dengan rata-rata 7.7 atau dibulatkan menjadi 8. Sedang pada Full Day School pada SDIT Al-Hidayah mendapat skor 111 dan dengan rata-rata 3.7 atau dibulatkan menjadi 4 dan pada SD Integral Luqman Al-
Hakim mendapat skor 118 dan dengan ratarata 3.9 atau dibulatkan menjadi 4 .

\section{Keseimbangan Statis}

Pada bulan Mei peneliti mengadakan penelitian sekolah yang dimaksud dengan tujuan mendapatkan informasi terkait penelitian yang dilakukan peneliti. Untuk data Tes Keseimbangan Statis diperoleh data sebagai berikut :

Tabel 3. Hasil tes Keseimbangan Statis

\begin{tabular}{cccc}
\hline \multicolumn{2}{c}{ Regular Schooll } & \multicolumn{2}{c}{ Full Day Schooll } \\
\hline SDN Pangarangan V & SDN Pangarangan I & SDIT Al-Hidayah & SD Integral Luqman Al-Hakim \\
\hline 677 & 730 & 571 & 540 \\
\hline 22.56 & 24.33 & 19.03 & 18 \\
\hline
\end{tabular}

Dari data hasil tes tersebut dapat diketahui bahwasannya pada hasil Keseimbangan Statis Regular Schooll pada SDN Pangarangan V mendapat skor 677 dan dengan rata-rata 22.56 dan masuk pada kategori Sedang. Pada SDN Pangarangan I mendapat skor 730 dan dengan rata-rata 24.33 dan masuk pada kategori Sedang. Sedangkan pada Full Day School pada SDIT Al-Hidayah mendapat skor 571 dan dengan rata-rata 19.03 dan masuk pada kategori Sedang. Pada sekolah SD Integral Luqman
Al-Hakim mendapat skor 540 dan dengan rata-rata 18 dan masuk pada kategori Sedang.

\section{Menendang Bola}

Pada bulan Mei peneliti mengadakan penelitian sekolah yang dimaksud dengan tujuan mendapatkan informasi terkait penelitian yang dilakukan peneliti. Untuk data Tes Menendang Bola diperoleh data sebagai berikut :

Tabel 4. Hasil tes Menendang Bola

\begin{tabular}{cccc}
\hline \multicolumn{2}{c}{ Regular Schooll } & \multicolumn{2}{c}{ Full Day School } \\
\hline SDN Pangarangan V & SDN Pangarangan I & SDIT Al-Hidayah & $\begin{array}{c}\text { SD Integral } \\
\text { Luqman Al-Hakim }\end{array}$ \\
\hline 95 & 139 & 73 & 71 \\
\hline 3.16 & 4.63 & 2.43 & 2.36 \\
\hline
\end{tabular}

Dari data hasil tes tersebut dapat diketahui bahwasanya pada hasil Menendang Bola Regular School pada SDN Pangarangan $\mathrm{V}$ mendapat skor 95 dan dengan rata-rata 3.1 dan masuk pada kategori Kurang. Pada SDN Pangarangan I mendapat skor 139 dan dengan rata-rata 4.6 dan masuk pada kategori Kurang. Sedangkan pada Full Day School pada SDIT Al-Hidayah mendapat skor 73 dan dengan rata-rata 2.4 
Jurnal Kejaora: Jurnal Kesehatan Jasmani dan Olah Raga

ISSN: 2541-5042 (Online)

ISSN: 2503-2976 (Print)

Volume 5 Nomor 2, Edisi November 2020

dan masuk pada kategori Sangat Kurang. Pada sekolah SD Integral Luqman Al-Hakim mendapat skor 71 dan dengan rata-rata 2.3 dan masuk pada kategori Sangat Kurang.

tujuan mendapatkan informasi terkait penelitian yang dilakukan peneliti. Untuk data Tes Kelincahan diperoleh data sebagai berikut :

\section{Kelincahan}

Pada bulan Mei peneliti mengadakan penelitian sekolah yang dimaksud dengan

Tabel 5. Hasil tes Kelincahan

\begin{tabular}{cccc}
\hline \multicolumn{2}{c}{ Regular School } & \multicolumn{2}{c}{ Full Day School } \\
\hline SDN Pangarangan V & SDN Pangarangan I & SDIT Al-Hidayah & SD Integral Luqman Al-Hakim \\
\hline 415 & 390 & 457 & 471 \\
\hline 13.83 & 13 & 15.23 & 15.7 \\
\hline
\end{tabular}

Dari data hasil tes tersebut dapat diketahui bahwasanya pada hasil Kelincahan pada Regular School pada SDN Pangarangan $\mathrm{V}$ mendapat skor 415 dan dengan rata-rata 13.83 dan masuk pada kategori Sedang. Pada SDN Pangarangan I mendapat skor 390 dan dengan rata-rata 13 dan masuk pada kategori Baik. Sedangkan

Tabel 6. Hasil Gabungan Seluruh Tes

\begin{tabular}{|c|c|c|c|c|c|c|c|c|}
\hline NAMA & KOMATA & NORMA & KESEIMBANGAN & NORMA & KETEPATAN & NORMA & KELINCAHAN & NORMA \\
\hline 1 SON PANGARANGAN V (REGULER) & 6 & & 22 & SEDANG & 3 & KURANG & 13.83 & SEDANG \\
\hline 2 SON PANGARANGAN I (REGULER) & 8 & & 24 & BAIK & 5 & CUKUP & 13 & BAIK \\
\hline 3 SOITALHIDAYAH (FULL DAY) & 4 & & 19 & SEDANG & 2 & S.KURANG & 15.23 & KURANG \\
\hline 4 SO INTEGRAL LUQMAN AL:HAKIM (FULLDAY) & 4 & & 18 & SEDANG & 2 & S. KURANG & 15.7 & KURANG \\
\hline
\end{tabular}

Dari data gabungan berikut ini dapat diketahui Gross Motor Activity dari sekolah yang menerapkan sistem full day Schooll dan regular Schooll. Berikut merupakan data hasil dari kedua sekolah tersebut :

\section{Full Day School}

Pada tes kordinasi mata tangan diperoleh skor 4 untuk masing -masing sekolah tersebut sehingga hasil penggabungan skor dari 2 sekolah tersebut adalah skor 4. Dimana pada tes koordinasi mata dan tangan ini tidak ada norma baku yang dapat dijadikan patokan untuk menentukan menentukan kategori atau norma dari tes tersebut.

Pada tes Keseimbangan Statis diperoleh skor 19 untuk sekolah SDIT AIHidayah dan skor 18 untuk sekolah SD pada Full Day School pada SDIT Al-Hidayah mendapat skor 457 dan dengan rata-rata 15.23 dan masuk pada kategori Kurang. Pada sekolah SD Integral Luqman Al-Hakim mendapat skor 471 dan dengan rata-rata 15.7 dan masuk pada kategori Kurang.
Integral Luqman Al-Hakim sehingga diperoleh skor rata-rata dari kedua sekolah tersebut adalah 18,5 dimana ini termasuk pada kategori sedang untuk norma tes keseimbangan statis yang dalam perhitungan ini menggunakan acuan detik pada setiap skor dimana ketika seseorang yang waktunya lebih banyak maka akan semakin bagus pula tingkat keseimbangan statis orang tersebut.

Pada tes menendang bola (ketepatan) diperoleh skor 2 dari masingmasing sekolah tersebut sehingga skor gabungan dari dua sekolah tersebut adalah skor 2 dimana pada tes menedang bola termasuk pada kategori Sangat Kurang. 
Pada tes kelincahan diperoleh skor 15.23 untuk sekolah SDIT AI-Hidayah dan skor 15.7 untuk sekolah SD Integral Luqman Al-Hakim sehingga skor rata-rata atau penggabungan dari dua sekolah tersebut adalah 15.46 yang masuk pada kategori Sangat Kurang. Disini catatan waktu yang dipakai adalah detik sehingga semakin sedikit jumlah detik yang dihasilkan maka orang tersebut semakin baik pula tingkat kelincahanya.

\section{Regular Schooll}

Pada tes kordinasi mata tangan diperoleh skor 6 untuk sekolah SDN Pangarangan $V$ dan Skor 8 untuk SDN Pangarangan I tersebut sehingga hasil penggabungan skor dari 2 sekolah tersebut adalah skor 7. Dimana pada tes koordinasi mata dan tangan ini tidak ada norma baku yang dapat dijadikan patokan untuk menentukan menentukan kategori atau norma dari tes tersebut.

Pada tes Keseimbangan Statis diperoleh skor 22 untuk sekolah SDN Pangarangan $V$ dan skor 24 untuk sekolah SDN Pangarangan I sehingga diperoleh skor rata-rata dari kedua sekolah tersebut adalah 23 dimana ini termasuk pada kategori sedang untuk norma tes keseimbangan statis yang dalam perhitungan ini menggunakan acuan detik pada setiap skor dimana ketika seseorang yang waktunya lebih banyak maka akan semakin bagus pula tingkat keseimbangan statis orang tersebut.

Pada tes menendang bola (ketepatan) diperoleh skor 3 SDN Pangarangan $V$ da Skor 5 untuk SDN Pangarangan I sehingga skor gabungan dari dua sekolah tersebut adalah skor 4 dimana pada tes menedang bola termasuk pada kategori Kurang.

Pada tes kelincahan diperoleh skor 13.83 untuk SDN Pangarangan $V$ dan skor 13 untuk sekolah SDN Pangarangan I sehingga skor rata-rata atau penggabungan dari dua sekolah tersebut adalah 13.41 yang masuk pada kategori Baik. Disini catatan waktu yang dipakai adalah detik sehingga semakin sedikit jumlah detik yang dihasilkan maka orang tersebut semakin baik pula tingkat kelincahanya.

Sementara itu kemampuan akademik siswa yang diperkuat oleh Kiram (1992:4) bahwa pendidikan jasmani di sekolah dasar pada hakekatnya mempunyai arti, peran fungsi yang amat vital dalam upaya menciptakan suatu masyarakat yang sehat dan dinamis. Pendidikan jasmani dapat menyalurkan hasrat dan keinginan peserta didik untuk bergerak. Bergerak tidak hanya merupakan kebutuhan alami peserta didik usia sekolah dasar, melainkan dari sisi lain juga dapat membentuk, membina dan mengembangkan individu peserta didik. Dari pendapat tersebut tentua akan bertentangan dengan Full Day School dimana sekolah tersebut lebih mengutamakan akademik siswa dibandingkan non akademik siswa.

Dari data tersebut jelas terlihat bahwa regular School lebih dominan atau lebih baik dalam hal yang berhubungan dengan gerak dasar atau motor ability. Hal ini tetntu akan berdampak terhadap tingkat kebugaran siswa pada kedua sekolah tersebut. Secara lebih spesifik rumusan tujuan penjas dijabarkan ke dalam pendidikan kesehatan, menurut Rusdiyanto (2018) bahwa "pendidikan jasmani olahraga di sekolah mengemban tiga misi yaitu satu diantaranya pendidikan jasmani dengan sasarannya domain kognitif, afektif, dan psikomotor dalam pengertian yang luas dan bersifat mendasar". Penjas di sekolah sarat dengan aktivitas fisik (aspek psikomotor), begitu juga perkembangan aspek kognitif dan afektif siswa merupakan satu kesatuan yang tidak terpisahkan satu sama lainnya yang berupa hasil belajar. Hasil belajar tersebut diharapkan menjadi kesatuan yang utuh sehingga terbentuk peserta didik yang sadar kesehatan, kebugaran, dan keterampilan sosial dalam mempersiapkan kehidupan dimasa yang akan datang.

\section{KESIMPULAN}

Berdasarkan hasil yang yang diperoleh dari data hasil yang telah dihitung disini Regular School mendapatkan hasil yang lebih baik daripada Full Day School. Ini bisa saja terjadi karena waktu istirahat dan 
Jurnal Kejaora: Jurnal Kesehatan Jasmani dan Olah Raga

ISSN: 2541-5042 (Online)

ISSN: 2503-2976 (Print)

Volume 5 Nomor 2, Edisi November 2020

waktu untuk bermain siswa Regular Schooll lebih banyak sehingga pada sore hari bisa memanfaatkan waktunya untuk bermain atau melakukan kegiatan pelatihan pada klub-klub yang ada di sekitar rumah tempat tinggal mereka sesuai bakat minat mereka sendiri. Pada siswa Full Day School adalah kurangnya waktu bermain untuk mereka karena banyak waktunya yang telah dihabiskan di sekolah sehingga ketika pulang rumah sudah pada kondisi kurang fit sehingga akan tidak sempat melakukan kegiatan bermain yang tujuanya untuk mengasah Gross Motor Ability atau kegiatan yang menggunakan otot besar atau disebut juga motorik kasar.

\section{UCAPAN TERIMA KASIH}

Penelitian ini dibiayai oleh DRPM RISTEKDIKTI berdasarkan Surat Keputusan Nomor 083/SP2HL/LT/DRPM/2020 tanggal 09 Maret 2020 tentang Penetapan Pemenang Hibah Penelitian Dosen Pemula Tahun Anggaran 2019. Terimakasih kami sampaikan sehingga penelitian ini dapat dilaksanakan dan semoga nantinya hasil penelitian ini dapat bermanfaat.

\section{DAFTAR PUSTAKA}

Baharuddin. (2010). Pendidikan dan Psikologi Perkembangan. Ar-Ruzz Media.

Joyce, B. and Weil, M. (2000). Models of Teaching (5th ed.). Allyn and Bacon.

Kiram, P. Y. (1992). Belajar Motorik. Departemen Pendidikan dan Kebudayaan Direktorat Jenderal Pendidikan Tinggi Proyek Pembinaan Tenaga Kependidikan.

Maksum, A. (2012). Metodelogi Penelitian Dalam Olahraga. Unesa University Press.

Pemerintah Republik Indonesia. (2007). Peraturan Pemerintah Nomor 16 Tahun 2007. www.hukumonline.com

Prasetyo Baskoro Adi. (2010). Seminar Nasional Pendidikan Biologi FKIP UNS 2010 Seminar Nasional Pendidikan Biologi FKIP UNS 2010 155. 154-163. http://www.ejurnal.com/2015/02/analisiskeragaman-dna-tanaman-durian.html 